\title{
HIERACIUM SUDETOTUBULOSUM (ASTERACEAE) REDISCOVERED OUTSIDE THE KARKONOSZE MTS
}

\author{
ZBigniew SzeląG \& GrZegorz WóJCiK
}

\begin{abstract}
Hieracium sudetotubulosum Szeląg [= H. tubulosum (Tausch) Tausch, nom. illeg.], considered to be endemic to the Karkonosze/Krkonoše Mts, has been found on Mt. Szczeliniec Wielki in the Góry Stołowe Mts, SW Poland. This is the easternmost occurrence of the species, disjoined from its continuous geographical range in the Karkonosze Mts by ca $50 \mathrm{~km}$. The occurrence of H. sudetotubulosum on Mt. Szczeliniec Wielki was published by Zahn in 1938 but it was overlooked in the modern literature.
\end{abstract}

Key words: Asteraceae, endemic, Hieracium alpinum agg., Poland, relict locality, Sudetes

Zbigniew Szelag, Institute of Botany, Jagiellonian University, Kopernika 31, 31-501 Kraków, Poland; e-mail: azszelag@wp.pl Grzegorz Wójcik, Department of Pharmaceutical Biology and Botany, Wroclaw Medical University, Al. Jana Kochanowskiego 10, 51-601 Wrocław, Poland; e-mail: grzegorz.wojcik@umed.wroc.pl

In August 2012, Grzegorz Wójcik collected on Mt. Szczeliniec Wielki (German: Heuscheuer) in the Góry Stołowe Mts, Central Sudetes, SW Poland, a plant from the Hieracium alpinum aggregate that was already in the fruiting stage and not amenable to precise determination. To determine its taxon, in June 2013 we both visited the Góry Stołowe Mts and found that the Mt. Szczeliniec Wielki plants represent $H$. sudetotubulosum Szeląg, a high mountain species known to date from the Karkonosze/Krkonoše Mts $50 \mathrm{~km}$ distant (Fig. 1). Hieracium sudetotubulosum was validated as a new name for the illegitimate name $H$. tubulosum (Tausch) Tausch (Szeląg 2014). The species differs from other Central European species of the $H$. alpinum aggregate by having tubular florets (Fig. 2). Its complete description was given by Chrtek (1997, 2004).

Hieracium sudetotubulosum grows on the upper verge of Mt. Szczeliniec Wielki NW cliff (Fig. 2), next to a lookout at 890-900 m a.s.1., where we found $c a 90$ individuals in flower. We also found a few plants on shaded rocks close to a mountain hut at $910 \mathrm{~m}$ a.s.l. The most numerous population, ca 200 plants, was at the foot of the northwest face of the mountain at 850-860 $\mathrm{m}$ a.s.1. We estimate the total $H$. sudetotubulosum popula- tion from Mt. Szczeliniec Wielki to be $400-500$ plants. Most of them occur in less accessible places in crevices of the vertical faces of rocks forming a 40-meter cliff. Hieracium sudetotubulosum probably occurs in other parts of Mt. Szczeliniec Wielki as well.

The mountain Hieracia of the Sudetes were studied continuously by Czech and German botanists beginning in the early $19^{\text {th }}$ century, and summarized by Zahn in his second monograph

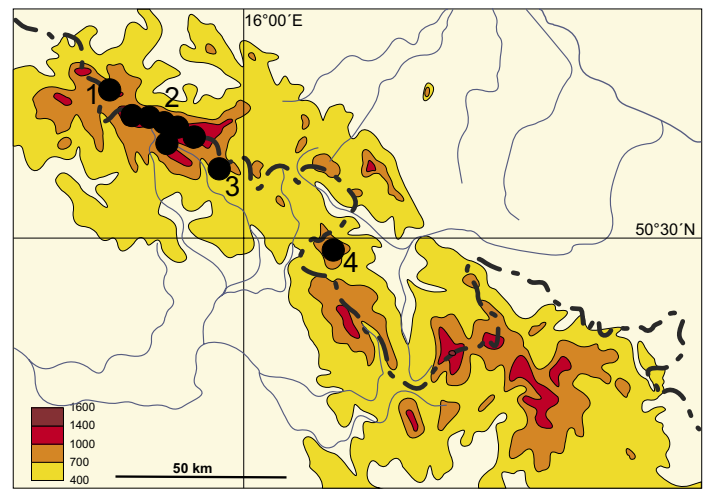

Fig. 1. Distribution of Hieracium sudetotubulosum Szeląg. 1 Góry Izerskie Mts (extinct locality), 2 - Karkonosze/Krkonoše Mts, 3 - Rýchory Mts (easternmost part of the Czech Krkonoše Mts), 4 - Góry Stołowe Mts. 

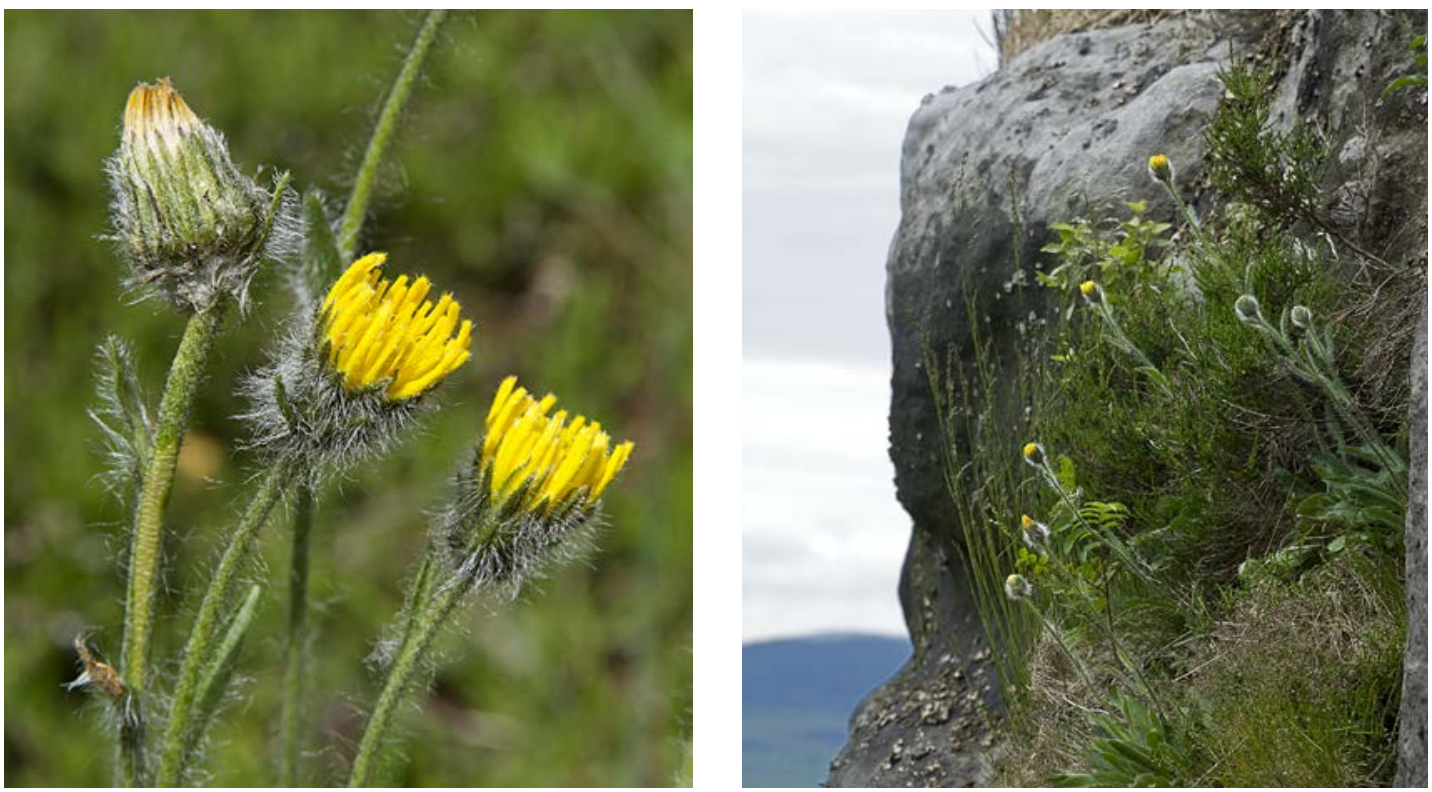

Fig. 2. Flowering Hieracium sudetotubulosum Szeląg on Mt. Szczeliniec Wielki (Photo G. Wójcik 2013).

(Zahn 1938), and by Zlatník (1938, 1939). A new taxonomic revision of Hieracium sect. Alpina (Griseb.) Gremli in the Sudetes was made by Chrtek (1995, 1997). A summation of all these studies was published in Květena České Republiky (Chrtek 2004).

Chrtek (2004) distinguished four species within the H. alpinum aggregate in the Sudetes: H. alpinum L. in the Karkonosze/Krkonoše Mts and Hrubý Jeseník Mts, H. schustleri Zlatník in the Karkonosze/Krkonoše Mts and on Mt. Śnieżnik Kłodzki/Králický Sněžník, H. melanocephalum Tausch endemic to the Karkonosze/Krkonoše Mts, and H. tubulosum (Tausch) Tausch in the Karkonosze/Krkonoše Mts and Góry Izerskie Mts, the latter station based on an old collection discovered recently in GLM by Bräutigam (2001).

According to Zahn (1938), however, the range of $H$. tubulosum is much wider and, besides the Karkonosze Mts, reaches Mt. Śnieżnik Kłodzki and the Hrubý Jeseník Mts in the Eastern Sudetes, and even the Tatra Mts in the Western Carpathians. He also mentions the Góry Stołowe Mts and Mt. Iwinka in the Góry Bialskie Mts among its locations.
Chrtek (1997) considers only some of the stations enumerated by Zahn (1938), including the Mt. Śnieżnik Kłodzki plants into H. schustleri (see also Chrtek 1995: 100), while generally regarding as erroneous the information on the occurrence of H. tubulosum in the Hrubý Jeseník Mts and Tatra Mts. It is not clear whether Jindřich Chrtek personally examined the herbarium material from the Tatras and Hrubý Jeseník Mts determined by Zahn as $H$. tubulosum, as the specimens are not on the list of specimens he examined.

The remaining locations of $H$. tubulosum cited by Zahn (1938: 154), 'Heuscheuer' (Mt. Szczeliniec Wielki in the Góry Stołowe Mts) and 'Saalwiesen bei Landeck' (Mt. Iwinka in the Góry Bialskie Mts), were omitted in the revision of the H. alpinum aggregate in the Sudetes by Chrtek (1995, 1997). Our rediscovery of H. sudetotubulosum on Mt. Szczeliniec Wielki casts a new light on Zahn's statement on its occurrence outside the Karkonosze Mts.

In the Sudetes the high mountain Hieracia are concentrated in the Karkonosze Mts in the Western Sudetes, and in the Hrubý Jeseník Mts and Mt. Śnieżnik Kłodzki in the Eastern Sudetes (Benner 
1905; Zlatník 1938; Skřivánek 1956; Šourek 1969; Szeląg 2000; Chrtek 2004). Mt. Szczeliniec Wielki is the only station of high mountain Hieracium species situated between the Karkonosze Mts and Mt. Śnieżnik Kłodzki. At the same time, it is one of the lowest locations of $H$. sudetotubulosum, which in the Karkonosze Mts occurs mainly in the subalpine zone. The presence of $H$. sudetotubulosum on Mt. Szczeliniec Wielki at 850-910 m a.s.l. is possible owing to the specific habitat and microclimatic conditions of the rock cliffs elevated above the surrounding Picea abies forest (Fig. 2).

AcKnowledgements. We thank Janusz Korybo, Director of Góry Stołowe Mountains National Park, for permission to do field research in the National Park. We are obliged to an anonymous reviewer and especially to Dr. Jindřich Chrtek (Průhonice) for his comments to an earlier version of this paper.

\section{REFERENCES}

BenNer E. 1905. Die Hieracien des Riesengebirges aus den Sektionen Alpina und Alpestria in ihren phylogenetischen Beziehungen zu andern Verwandtschaftskreisen. H. Fleischmann, Breslau.

BRÄUTIGAM S. 2001. Ungewöhnliche Arten der Gattung Hieracium subgen. Hieracium aus dem Isergebirge im Görlitzer Herbarium. Przyroda Sudetów Zachodnich 4: 15-18.
ChrTeK J. 1995. Notes on Hieracium alpinum and Hieracium nigrescens groups (section Alpina Fries in the Eastern Sudeten (Mt. Králický Sněžník, the Hrubý Jeseník Mts.). Preslia 67: 97-106.

ChrTeK J. 1997. Taxonomy of the Hieracium alpinum group in the Sudeten Mts., the West and the Ukrainian East Carpathians. Folia Geobot. Phytotax. 32: 69-97.

Chrtek J. 2004. Hieracium L. In: B. Slavík, J. ŠtěPáNKová \& J. ŠTĚPÁNeK (eds), Květena Česke Republiky. 7: 540701. Academia, Praha.

SkřIVÁNEK V. 1956. Beitrag zur Verbreitung der Gattung Hieracium im Hohen Gesenke. Prrir. Sborn. Ostravsk. Kraje 17: 397-405 (in Czech with German summary).

ŠoureK J. 1969. Květena Krkonoš. Český a Polský Krkonošský Národni Park. Academia, Praha.

SzELĄG Z. 2000. Vascular plants of the Śnieżnik Massif and the Góry Bialskie Mts. Fragm. Florist. Geobot., Ser. Polon., Suppl. 3: 3-255 (in Polish with English summary).

SzelĄG Z. 2014. Hieracium sudetotubulosum (Asteraceae), a new name for the illegitimate $H$. tubulosum (Tausch) Tausch. Phytotaxa 156(4): 250.

ZAHN K. H. 1938. Hieracium. In: P. GRÄBNER FIL. (ed.), Synopsis der Mitteleuropäischen Flora. 12(3): 1-708. Borntraeger, Berlin.

ZlatníK A. 1938. Hieracia Alpina Sudetorum Occidentalium. Stud. Bot. Čechosl. 1: 37-51, 105-242.

ZlatNíK A. 1939. Additamentum ad Hieracia Alpina Sudetorum Occidentalium. Stud. Bot. Čechosl. 2: 64-96. 